POLITEIA
POLITEIA: Jurnal Ilmu Politik
Politeia: Jurnal Ilmu Politik, 10 (2) (2018): 79-90
ISSN 0216-9290 (Print), ISSN 2549-175X (Online)
Available online https://jurnal.usu.ac.id/index.php/politeia

\title{
Ilusi Demokrasi Substansial di Indonesia: Sebuah Kritik Terhadap Impementasi Parliamentary Treshlod
}

\author{
Fuad Putera Perdana Ginting1)* \& Anwar Saragih² \\ 1Program Studi Ilmu Pemerintahan, Fakultas Ilmu Sosial dan Politik \\ Universitas Medan Area, Indonesia \\ 2S75 Branding House, Indonesia
}

Diterima Maret 2018; Disetujui Mei 2018; Dipublikasikan Juli 2018

\begin{abstract}
Abstrak
Penelitian ini mengangkat pembahasan mengenai Ilusi Demokrasi Substansial Di Indonesia: Sebuah Kritik Terhadap Implementasi Parliamentary Theshold. Sejak pemilihan umum 2009. Indonesia mulai memperkenalkan sistem ambang batas parlemen (Parliamentary Theshold) yang menetapkan ambang batas 2,5\%. Kemudian di Pemilu berikutnya, pemilu 2014 melalui naik menjadi 3,5\% dengan semangat penyederhanaan jumlah partai di parlemen. Namun, nyatanya hal tersebut tidak terjadi. Sebab, jumlah partai politik hasil pemilu 2009 yang merupakan 9 partai justru bertambah menjadi 10 partai di pemilu 2014. Terdapat permasalahan lain dalam sistem pemilu yang menggunakan Parliamentary Theshold. Seperti di pemilu 2009 ada 29 partai politik yang suaranya hilang akibat sistem ini, kemudian di pemilu 2014 ada 2 partai politik yang suara yang juga hilang akibat sistem ambang batas tersebut. Tentu, sebagai sebuah demokrasi rakyat harus tahu kemana suaranya tersebut. Apakah sistem pemberlakuan sistem Parliamentary Theshold dalam pemilu Indonesia sudah sesuai dengan esensi demokrasi substansial? Hasil dari penelitian ini menunjukan sistem parliamentary threshold berdampak pada hilangnya suara partai kecil, pemilihan presiden yang transaksional dan parliamentary threshold membatasi hak demokrasi. Indonesia membutuhkan sistem pemilu yang jujur, bebas, berkualitas, transparan dan mewakili keinginan mayoritas raktat Indonesia.
\end{abstract}

Kata Kunci: Pemilu, Parliamentary Theshold, Ilusi Demokrasi

\begin{abstract}
This study raises a discussion about the Illusion of Substantial Democracy in Indonesia: A Criticism of the Implementation of Theshold's Parliamentary. Since the 2009 general election. Indonesia has begun to introduce a parliamentary threshold system (Parliamentary Theshold) which sets a $2.5 \%$ threshold. Then in the next election, the 2014 election rose to $3.5 \%$ in the spirit of simplifying the number of parties in parliament. However, in fact this did not happen. Because, the number of political parties resulting from the 2009 elections which were 9 parties actually increased to 10 parties in the 2014 election. There were other problems in the electoral system using Theshold Parliamentary. As in the 2009 elections there were 29 political parties whose voices were lost due to this system, then in the 2014 elections there were 2 political parties who also lost votes due to the threshold system. Of course, as a democracy the people must know where the voice is. Is the system of implementing the Theshold Parliamentary system in the Indonesian elections in line with the essence of substantial democracy? The results of this study indicate the parliamentary threshold system has an impact on the loss of the voice of small parties, transactional presidential elections and the parliamentary threshold limiting democratic rights. Indonesia needs an electoral system that is honest, free, high-quality, transparent and represents the wishes of the majority of Indonesia's ractates
\end{abstract}

Keyword: Elections, Parliamentary Threshold and Illusion of Democracy

How to Cite: Ginting, F.P.P. \& Saragih, A. (2018). Ilusi Demokrasi Substansial di Indonesia: Sebuah Kritik Terhadap Implementasi Parliamentary Treshold, Politeia: Jurnal Ilmu Politik, 10 (2): 79-90

\footnotetext{
*Corresponding author:

E-mail: fuadginting@gmail.com
} 


\section{PENDAHULUAN}

Sejak reformasi 1998 bergulir, dimulailah geliat politik di Indonesia dengan munculnya partai-partai politik baru yang mustahil terwujud di masa orde baru. Dampaknya pada pemilu 1999, pemilihan umum diikuti oleh 48 partai politik Terjadi dilema yang luar biasa, disatu sisi, fenomena ini bisa jadi hanya sebuah efuria demokrasi, disisi yang lain timbul kebingungan publik akan preferensi politiknya. Masyarakat yang terbiasa diarahkan pada partai politik tertentu di masa orde baru menjadi kaget harus berhadapan dengan banyaknya partai politik.

Pada tahun 2004, masyarakat Indonesia dihadapkan pada permasalahan yang sama. Kebingungan akan menentukan preferensi politiknya. Walaupun pada pemilu legislatif kali ini jumlah partai politikpeserta pemilu menurun hingga 50\% menjadi hanya 24 peserta pemilu saja. Namun, dibingungkan antara kesamaan-kesamaan platform partai-partai tersebut. Ditahun yang sama pula publik mengikuti pemilihan presiden secara langsung. Babak baru sistem demokrasi di Indonesia yang selama ini dipilih oleh majelis Permusyaratan rakyat (MPR).

Artinya reformasi membawa tiga warna baru dalam sistem pemilu di Indonesia. Pertama, Kembalinya Indonesia kedalam sistem multipartai seperti pemilu 1955 (Perdana, 2014). Kedua, di pemilu 2014 Pemilu berlangsung dua kali, pertama memilih wakil rakyat dan selanjutnya memilih presiden secara langsung. Ketiga, Sesuai dengan PP Nomor 6 tahun 2005 tentang pemilihan, pengesahan pengangkatan dan pemberhentian Kepala Daerah dan wakil kepala daerah maka dilangsungkan Pemilukada (pemilihan kepala daerah) sesuai dengan amanat UU No 32 tahun 2004 (Alkatiri, 2014).

Setahun sebelum pemilu 2009, melalui Dewan Perwakilan Rakyat (DPR) pemerintah mulai diberlakukan ketentuan ambang batas perolehan kursi parlemen (Parliamentary Threshold). Parliamentary threshold dalam kamus Oxford Advanced Learner's Dictionary, terdiri dari kata parliament yang berarti sekumpulan orang yang terpilih untuk membuat dan merubah hukum di suatu negara (the group of people who are elected to make and change the laws of a country) dan threshold yang berarti batasan tertentu untuk memulai sesuatu (the level at which sth starts to happen).

Secara garis besar, parliamentary threshold berarti batasan tertentu untuk bisa memilih sekumpulan orang yang membuat dan merubah hukum di suatu negara.Ambang batas parlemen atau parliamentary threshold, merupakan salah satu instrumen teknis pemilu yang ditemui dalam negara-negara yang menerapkan sistem pemilu proporsional, termasuk di Indonesia (Higashikata \& Kwamura, 2015)

Setahun sebelum pemilu 2009, melalui Dewan Perwakilan Rakyat (DPR) pemerintah mulai diberlakukan ketentuan ambang batas perolehan kursi parlemen (Parliamentary Threshold). Parliamentary threshold dalam kamus Oxford Advanced Learner's Dictionary, terdiri dari kata parliament yang berarti sekumpulan orang yang terpilih untuk membuat dan merubah hukum di suatu negara (the group of people who are elected to 
make and change the laws of a country) dan threshold yang berarti batasan tertentu untuk memulai sesuatu (the level at which sth starts to happen) (Dahlan, 2015)

Secara garis besar, parliamentary threshold berarti batasan tertentu untuk bisa memilih sekumpulan orang yang membuat dan merubah hukum di suatu negara.Ambang batas parlemen atau parliamentary threshold, merupakan salah satu instrumen teknis pemilu yang ditemui dalam negara-negara yang menerapkan sistem pemilu proporsional, termasuk di Indonesia (Dahlan, 2015).

Ketentuan ini tercantum dalam Pasal 202 Undang-Undang Nomor 10 Tahun 2008 tentang Pemilihan Umum yang menyatakan bahwa partai politik peserta Pemilihan Umum harus memenuhi sekurangkurangnya Tabel.1.1. Hasil Pemilu 2009

\begin{tabular}{|l|l|l|l|}
\hline $\begin{array}{l}\text { No } \\
\text { Urut }\end{array}$ & Partai Politik & Jumlah Suara & $\begin{array}{l}\text { Persentase } \\
\text { Suara }\end{array}$ \\
\hline 1 & Partai Hati Nurani Rakyat & 3.922 .870 & $3.77 \%$ \\
\hline 2 & Partai Karya Peduli Bangsa & 1.461 .182 & $1.40 \%$ \\
\hline 3 & Partai Pengusaha dan Pekerja Indonesia & 745.625 & $0.72 \%$ \\
\hline 4 & Partai Peduli Rakyat Nasional & 1.260 .794 & $1.21 \%$ \\
\hline 5 & Partai Gerakan Indonesia Raya & 4.646 .406 & $4.46 \%$ \\
\hline 6 & Partai Barisan Nasional & 761.086 & $0.73 \%$ \\
\hline 7 & Partai Keadilan dan Persatuan Indonesia & 934.892 & $0.90 \%$ \\
\hline 8 & Partai Keadilan Sejahtera & 8.206 .955 & $7.88 \%$ \\
\hline 9 & Partai Amanat Nasional & 6.254 .580 & $6.01 \%$ \\
\hline 10 & Partai Perjuangan Indonesia Baru & 197.371 & $0.19 \%$ \\
\hline 11 & Partai Kedaulatan & 437.121 & $0.42 \%$ \\
\hline 12 & Partai Persatuan Daerah & 550.581 & $0.53 \%$ \\
\hline 13 & Partai Kebangkitan Bangsa & 5.146 .122 & $4.94 \%$ \\
\hline 14 & Partai Pemuda Indonesia & 414.043 & $0.40 \%$ \\
\hline 15 & Partai Nasional Indonesia Marhaenisme & 316.752 & $0.30 \%$ \\
\hline 16 & Partai Demokrasi Pembaruan & 896.660 & $0.86 \%$ \\
\hline 17 & Partai Karya Perjuangan & 351.440 & $0.34 \%$ \\
\hline 18 & Partai Matahari Bangsa & 414.750 & $0.40 \%$ \\
\hline 19 & Partai Penegak Demokrasi Indonesia & 137.727 & $0.13 \%$ \\
\hline 20 & Partai Demokrasi Kebangsaan & 671.244 & $0.64 \%$ \\
\hline 21 & Partai Republika Nusantara & 630.780 & $0.61 \%$ \\
\hline 22 & Partai Pelopor & 342.914 & $0.33 \%$ \\
\hline 23 & Partai Golongan Karya & 15.037 .757 & $14.45 \%$ \\
\hline 24 & Partai Persatuan Pembangunan & 5.533 .214 & $5.32 \%$ \\
\hline & & & \\
\hline
\end{tabular}

2,5 persen suara dari jumlah suara sah secara nasional untuk diikutsertakan dalam penentuan perolehan kursi Dewan Perwakilan Rakyat (DPR). (Firdaus, 2010)

Lebih lanjut, di Pemilu 2009 yang diikuti oleh 38 partai politik dengan Penerapan angka ambang batas parlemen sebesar 2,5\%, jelas sangat berdampak jumlah partai politik di DPR. Hanya 9 (sembilan) parpol yang dapat melewati angka ambang batas parlemen sebesar 2,5\% yaitu PD $(20,85 \%)$, Partai Golkar (14,45\%), PDIP $(14,03 \%)$, PKS $(7,88 \%)$, PAN $(6,01 \%)$, PPP (5,32\%), PKB (4,94\%), Partai Gerindra $(4,46 \%)$ dan terakhir Partai Hanura (3,77\%). Sementara 29 partai lainnya tidak memiliki kesempatan untuk diikutkan pada pembagian kursi DPR karena suaranya tidak memenuhi standard ambang batas. 
Fuad Putera Perdana Ginting \& Anwar Saragih, Ilusi Demokrasi Substansial di Indonesia

\begin{tabular}{|l|l|l|l|}
\hline 25 & Partai Damai Sejahtera & 1.541 .592 & $1.48 \%$ \\
\hline 26 & Partai NBK Indonesia & 468.696 & $0.45 \%$ \\
\hline 27 & Partai Bulan Bintang & 1.864 .752 & $1.79 \%$ \\
\hline 28 & Partai Demokrasi Indonesia Perjuangan & 14.600 .091 & $14.03 \%$ \\
\hline 29 & Partai Bintang Reformasi & 1.264 .333 & $1.21 \%$ \\
\hline 30 & Partai Patriot & 547.351 & $0.53 \%$ \\
\hline 31 & Partai Demokrat & 21.703 .137 & $20.85 \%$ \\
\hline 32 & Partai Kasih Demokrasi Indonesia & 324.553 & $0.31 \%$ \\
\hline 33 & Partai Indonesia Sejahtera & 320.665 & $0.31 \%$ \\
\hline 34 & Partai Kebangkitan Nasional Ulama & 1.527 .593 & $1.47 \%$ \\
\hline 41 & Partai Merdeka & 111.623 & $0.11 \%$ \\
\hline 42 & Partai Persatuan Nahdlatul Umma Indonesia & 146.779 & $0.14 \%$ \\
\hline 43 & Partai Serikat Indonesia & 140.551 & $0.14 \%$ \\
\hline 44 & Partai Buruh & 265.203 & $0.25 \%$ \\
\hline Total & & 104.099 .785 & $100,00 \%$ \\
\hline
\end{tabular}

Sumber: Komisi Pemilihan Umum Indonesia 2009 (www.kpu.go.id $/$ )

Tabel 1.2. Hasil Suara Pemilihan Umum 2014

\begin{tabular}{|l|l|l|l|}
\hline $\begin{array}{l}\text { No } \\
\text { Urut }\end{array}$ & Partai Politik & Jumlah Suara & $\begin{array}{l}\text { Persentase } \\
\text { Suara }\end{array}$ \\
\hline 1 & Partai NasDem & 8.402 .812 & $6.72 \%$ \\
\hline 2 & Partai Kebangkitan Bangsa & 11.198 .957 & $9.04 \%$ \\
\hline 3 & Partai Keadilan Sejahtera & 8.480 .104 & $6.79 \%$ \\
\hline 4 & Partai Demokrasi Indonesia Perjuangan & 23.681 .471 & $18.95 \%$ \\
\hline 5 & Partai Golongan Karya & 18.432 .312 & $14.75 \%$ \\
\hline 6 & Partai Gerakan Indonesia Raya & 14.760 .371 & $11.81 \%$ \\
\hline 7 & Partai Demokrat & 12.728 .913 & $10.19 \%$ \\
\hline 8 & Partai Amanat Nasional & 9.481 .621 & $7.59 \%$ \\
\hline 9 & Partai Persatuan Pembangunan & 8.157 .488 & $6.53 \%$ \\
\hline 10 & Partai Hati Nurani Rakyat & 6.579 .498 & $5.26 \%$ \\
\hline 13 & Partai Bulan Bintang & 1.825 .750 & $1.46 \%$ \\
\hline 14 & Partai Keadilan dan Persatuan Indonesia & 1.143 .094 & $0.91 \%$ \\
\hline Total & & 104.099 .785 & $100,00 \%$ \\
\hline
\end{tabular}

Sumber: Komisi Pemilihan Umum Indonesia 2014 (www.kpu.go.id/)

Jika kita analisis, secara empirik bertujuan untuk mengurangi jumlah penetapan ambang batas parlemen partai di parlemen. Kondisi ini justru (Parliamentary Threshold) 2,5 \% di berbertolak belakang dengan pemilu 2009 dengan dasar regulasi semangat tersebut yang justru undang-undang Nomor 10 Tahun menambah jumlah partai di parlemen 2008 yang menghasilkan jumlah kursi dari 9 parpol di tahun 2009 menjadi 10 di parlemen 9 partai politik. Justru di pemilu berikutnya, pemilu tahun 2014 dengan penetapan ambang batas parlemen (Parliamentary Threshold) 3,5 $\%$ yang dasar regulasinya adalah undang-undang Nomor 8 Tahun 2012. Justru menambah jumlah partai politik di parlemen menjadi 10 partai politik.

Padahal secara substansi, diberlakukannya dan dinaikkannya angka Parliamentary Threshold parpol tahun 2014 di DPR.

Oleh karena itu diakhir tulisan ini berusaha melontarkan gagasan penghapusan Parliamentary Threshold. Sebab untuk memperbaiki kualitas demokrasi di Indonesia pemenuhan hak politik tidak hanya dipandang sebagai sebuah otonomi partai politik saja. Rakya juga berhak memastikan bahwa suaranya tidak hilang karena sistem ambang batas parlemen. Lebih lagi, secara empirik kita juga 
menyaksikan setiap pemilihan umum, suara partai yang tidak mencapai angka Parliamentary Threshold hilang. Padahal, sekecil apapun suara partai politik dengan sistem one man one vote rakyat berhak mengetahui kemana suara yang diberikan ketika pemilu berlangsung.

\section{METODE PENELITIAN}

Penelitian ini menggunakan metode Mix Method (metode campuran). Dimana peneliti mengumpulkan data secara sekuensial/bertahap (sequentialmixed methods) dengan metode kualitatif yang lebih dominan dari pada metode kuantitatif. Dimana peneliti mencoba mengabungkan data yang diperoleh dari satu metode dengan metode lainnya. Dengan metode kualitatif, peneliti mengumpulkan data dengan cara wawancara.

Kemudian, melalui strategi eksploratoris sekuensial, peneliti mengumpulan dan menganalisis data kualitatif dan selanjutnya mengumpulkan dan menganalisis data kuantitatif. Dimana tahapan dari kuantitatif merupakan hasil dari tahapan kualitatif. Metode kualitatif digunakan untuk menjelaskan fungsi dari instrumen-instrumen pada pemilu dan sumber data yang berasal dari deep interview.

Sementara, metode kuantitatif digunakan sebagai pembanding antara sistem dari pemilu ke sebelumnya dan sesudah diberlakukannya sistem abang batas parlemen (Parliamentary Threshold) beragam bentuk data kualitatif lainnya seperti dokumen yang berguna bagi pengembangan pemahaman lebih mendalam penelitian ini.
Dewan Perwakilan Rakyat Daerah Terhadap Undang-Undang Dasar 1945" menjelaskan Ambang batas perolehan suara adalah usaha memperoleh hasil pemilihan umum yang berkualitas dengan pengisian kursi di parlemen dan juga untuk menghasilkan pengelolaan pemerintah yang stabil. Namun cara ini selalu terbentur atau dibenturkan dengan persoalan demokrasi, disproporsionalitas pemilihan umum dan persoalan aspirasi rakyat.

Permasalahan yang diajukan dalam tulisan ini adalah apakah putusan Mahkamah Konstitusi atas permohonan uji materi tentang Ambang batas perolehan suara pemilu 2014 sudah tepat dan bagaimana penerapan yang tepat atas ambang batas perolehan suara pada pemilu 2014? Untuk menganalisis masalah ini menggunakan tipe penelitian normatif dengan data sekunder yang dianalisis dengan pendekatan kualitatif dan deduktif. Hasil penelitian ini menunjukkan bahwa penetapan ambang batas perolehan suara ditentukan sebesar $3.5 \%$ suara nasional hanya berlaku di jenjang nasional saja. Penetapan ambang batas perolehan suara tidak bertentangan dengan UndangUndang Dasar 1945. Penerapan atas ambang batas perolehan suara ini juga tidak tepat karena hanya diterapkan pada tataran nasional saja, karena sebaiknya penerapan ambang batas perolehan suara diterapkan di setiap jenjang. (Howard \& Ressler, 2006)

\section{HASIL DAN PEMBAHASAN \\ Hilangnya Suara Partai Kecil}

Demokrasi merupakan sebuah kondisi yang dianggap paling ideal 
dari sebuah negara yang dicitacitakan oleh banyak kalangan. Tetapi upaya menuju demokrasi yang ideal merupakan sebuah proses yang tidak mudah. Proses menuju demokrasi inilah yang disebut sebagai demokratisasi. Demokratisasi biasanya diawali dengan kebebasan (liberalisasi) (Firdaus, 2011). Dalam tahap ini media massa diberi kelonggaran sehingga tidak menghadapi ancaman pembredelan, masyarakat cukup leluasa melakukan partisipasi sosial melalui organisasi dan wahana lain, serta mulai berkembang penghargaan terhadap keragaman (pluralisme) (Nadir, 2005).

Demokrasi merupakan sebuah kondisi yang dianggap paling ideal dari sebuah negara yang dicitacitakan oleh banyak kalangan. Tetapi upaya menuju demokrasi yang ideal merupakan sebuah proses yang tidak mudah. Proses menuju demokrasi inilah yang disebut sebagai demokratisasi. Demokratisasi biasanya diawali dengan kebebasan (liberalisasi) (Meyer, 2012). Dalam tahap ini media massa diberi kelonggaran sehingga tidak menghadapi ancaman pembredelan, masyarakat cukup leluasa melakukan partisipasi sosial melalui organisasi dan wahana lain, serta mulai berkembang penghargaan terhadap keragaman (pluralisme). (Nadir, 2005)

Meminjam istilah Robert Dahl (1982), rezim demokrasi pemilihan memiliki empat unsur penunjang seperti universal, kelompok pemilihan yang aktif, hak yang universal dan pasif untuk memilih, pemilihan yang bebas dan adil. Artinya konsekuensi yang diakibatkan karena akses dan pegangan kekuasaan dalam negara bergantung kepada prefensi pemilih.
Pemilih dapat memberikan sangsi kepada wakil-wakil di parlemen yang terpilih. Tapi kontrol ini terbatas karena sifatnya hanya sebatas elit yang memerintah dan tidak memiliki pengaruh pada bagaimana cara kekuasaan dilaksanakan dari satu pemilihan kepada pemilih yang lain. (Herianto, 2006)

Sistem Parliamentary Theshold yang diterapkan di Indonesia dalam 2 periode pemilu terakhir seperti pemilu $2009(2,5 \%)$ dan pemilu 2014 $(3,5 \%)$. Secara empirik telah membuat suara partai politik yang suaranya tidak mampu mencapai angka Parliamentary Theshold akan hilang. Hal ini terjadi di pemilu 2009, dimana ada 29 partai politik yang suaranya hilang karena tidak mampu mencapai angka Parliamentary Theshold 2,5\%. Juga dengan pemilu 2014, dimana ada 2 partai yang suaranya juga hilang.

Menurut Fernanda Putra Adela yang merupakan dosen Ilmu Politik Universitas Sumatera Utara;

"Di Sumatera Utara kondisi ini pernah terjadi, Partai Peduli Rakyat Nasional (PPRN) yang berada di urutan ke-6 perolehan suara sementara di Sumut. Kemudian sebagai caleg DPR RI dari PPRN pada daerah pemilihan Sumut-I, dengan perolehan suara partai yang besar seharusnya mengantarkan Chandra Panggabean menjadi anggota dewan. Namun karena, partainya PPRN tidak lolos parliemantary threshold (PT) 2,5 persen nasional suara Chandra Panggabean hilang begitu saja".

Artinya penerapan ambang batas parlemen (parliamentary threshold) pasti akan berimplikasi pada terbuangnya atau hilangnya suara rakyat yang memilih di pemilihan umum. Lebih lagi, peningkatan ambang batas dari 2,5\% menjadi 3,5\% 
akan berimplikasi pada lebih banyak suara yang terbuang atau tidak terkonvesi menjadi kursi meski secara empiris kita menyaksikan penambahan kursi partai politik di parlemen dipemilu 2009 yang hanya 9 kursi dan di pemilu 2014 menjadi 10 kursi.

Hal ini kemudian ditegaskan kembali oleh Fernanda Putra Adela yang mengatakan; "Jika banyak suara pada saat pemilihan umum legislatif yang terbuang dan tidak bisa terkonvesi menjadi kursi di parlemen, maka dampaknya adalah disproporsionalitas alokasi kursi dalam sistem pemilu proporsional yang merupakan bagian dari sistem pemilu di Indonesia. Jika hal ini terjadi, maka bertentangan dengan Pasal $22 E$ ayat 3 Undang-Undang Dasar Negara Republik Indonesia Tahun 1945 yang secara khusus menghendaki sistem pemilu proporsional"

Prinsip keterwakilan dalam pemilihan umum dalam demokrasi substansi ini kemudian seharusnya tidak menimbulkan kesan politik berjangka pendek yang mengakomodasi hanya kepentingankepentingan lima tahunan saja, lebih daripada itu ini refomasi yang sifatnya lebih panjang lagi. Antara pemilu dan parlemen sangat berkaitan erat dengan pemerintahan perwakilan. Artinya, rakyat juga harus benar-benar tahu posisi suaranya yang menghasilkan perwakilan yang berkualitas dan tanggunggugat perwakilan yang bermakna. Pemilu yang berkualitas selalu menyediakan mekanisme yang adil bagi calon-calon wakil rakat, partai politik dan program yang dibawanya untuk saling berkompetisi memperoleh sebesar-besarnya dukungan dari warga masyarakat yang arahnya harus jelas.

\section{Implikasi penetapan angka ambang batas parlemen (Parliamentary Theshold)}

Undang-Undang Nomor 10 Tahun 2008 tentang Pemilihan Umum yang menjadi dasar regulasi pemilu 2009 dan undang-undang Nomor 8 Tahun 2012 yang menjadi dasar regulasi pemilu 2014 adalah diberlakukannya Presidential Threshold yang menurut regulasi undangundang sebelumnya mengatakan; "syarat utama dalam mencalonkan diri menjadi predisen perolehan suara nasional minimal $25 \%$ atau perolehan kursi dewan perwakilan Rakyat (DPR) minimal $20 \%$ suara nasional" (Cangara, 2009).

Artinya jika kondisi ini sudah terjadi maka koalisi partai politik tidak bisa dihindari sebab dengan sistem multi partai di Indonesia. Hampir mustahil partai politik tertentu mencapainya tunggal. Di pemilu 2009 lalu bahkan hanya Partai Demokrat yang bisa mencalonkan calon presiden sendiri karena suaranya mencapai $20.85 \%$ suara. Lebih parah, hasil pemilu 2014 yang menghasilkan tidak ada satu partai politikpun yang bisa mencalonkan presiden secara tunggal. Karena tidak ada partai politik hasil pemilu 2019 yang mampu mencapai $25 \%$ atau perolehan kursi dewan perwakilan Rakyat (DPR) minimal 20\% suara.

Dampaknya koalisi partai politik menjelang pemilu pun tidak bisa dihindari. Jika sudah begitu, maka akan rentan dengan politik transaksi dan politik bagi-bagi jabatan. Lebih lagi, secara teoritis sistem kepartaian Indonesia adalah sistem multipartai. Akibatnya setelah presiden terpilih, 
presiden harus membentuk koalisi di DPR untuk mengamankan dan memuluskan kebijakan-kebijakan yang akan diimplementasikan dalam pemerintahan sebab fungsi anggaran dan pengawasan merupakan wewenang di DPR. Hal itu yang membuat SBY harus mengakomodasi kepentingan-kepentingan partai politik dengan membentuk koalisi.

Kemudian faktor lain yang mendorong partai-partai politik dalam melakukan koalisi baik setelah atau sebelum pemilihan umum adalah partai politik mendapatkan jatah kekuasaan dari Presiden untuk mengisi pos menteri, duta besar (dubes) atau dirut BMUN/ direksi BUMD.

\section{Sistem Presidential Threshold menyebabkan rendahnya} keberlanjutan demokrasi dalam sistem presidensialisme. Sistem kepartaian seharusnya mendukung terbentuknya sistem pemerintahan yang kuat dan bersih serta meningkatkan efektifitas pemerintahan atau tingkat keterwakilan, namun kenyataannya setiap partai lebih mementingkan kepentingan masing-masing. Jika saja pengembangan institusionalisasi partai politik itu maksimal, tentu akan berimplikasi positif terhadap proses pemantapan sikap, dan perilaku partai politik yang terpola atau sistemik, sehingga terbentuk suatu budaya politik yang mendukung prinsip-prinsip dasar sistem demokrasi (Lijphart, 1995).

Fenomena demokrasi pasca Amandemen UUD 1945 telah melahirkan banyak partai politik, sebagai wadah sarana mereka untuk menyampaikan aspirasi, juga menambah kompleksitas hubungan yang terjadi antara lembaga legislatif dan eksekutif. Sistem Presidensial dan multipartai membuat instabilitasi demokrasi di Indonesia. Partai koalisi di DPR juga memiliki permasalahan tersendiri. Dapat dilihat bahwa koalisi yang terjadi di parlemen ternyata memiliki ideologis yang dengan jarak yang cukup jauh. Koalisi yang terjadi di parlemen hanya berdasarkan oleh kesamaan kepentingan tanpa melihat kesamaan visi dan ideologis dari partai-partai yang bergabung. Akibatnya koalisi yang dibentuk ini tidaklah solid dan rawan terjadi perpecahan dalam koalisi tersebut yang tentu akan membahayakan posisi seorang Presiden. (A.R, 2010)

Kita telah memiliki dua presfektif politik, peta ideologi partai yang berhubungan dengan kepentingan kolektif yang diwakili dan hasil-hasil pemilu. Teori koalisi berbasis ideologi berfokus pada pentingnya kesamaan ideologi dan kebijakan partai sebagai pertimbangan dalam membentuk koalisi. Diajukan oleh Abraham de Swaan (1973), teori ini menyatakan bahwa para politisi umumnya ingin meninggalkan jejak ideologis atau kebijakan dipemerintahan. Mereka tidak menjadikan jabatan kabinet sebagai tujuan akhir, melainkan sekadar sarana untuk menerapkan kebijakan tertentu. Karena memilih dan mempertahankan kebijakan tertentu. Karena memilih dan mempertahankan kebijakan terbaik menjadi dorongan utama, maka pertalian ideologis menjadi dasar pembentukan koalisi. Karena itu, besar-kecilnya koalisi dianggap tidak begitu penting. Dengan kata lain, besar-kecilnya koalisi tidak menjadi kriteria utama dalam merangkul atau mengesampingkan satu partai. 
Dengan demikian, tautan elektoral terwujud ketika komitmen ideologis partai yang dikampanyekan sebelum dan selama pemilu tetap mewarnai keputusan partai dalam memilih mitra koalisi (Ambardi, 2010).

Itu terjadi karena presiden tidak bisa mengelak dari desakan parpolparpol pendukung yang menyodorkan kadernya untuk masuk kabinet. Bagi presiden, selain memperluas dukungan di legislatif, koalisi juga dimaksudkan untuk mengikat komitmen partai politik untuk mendukung agenda-agenda pemerintah. Sedangkan bagi partai politik, koalisi berarti kesempatan untuk memaksimalkan kebijakan, kontrol dan pengaruh mereka terhadap jabatan-jabatan politik presiden.Berkaitan dengan komitmen, pembentukan kabinet koalisi mengandaikan, adanya kesepakatan yang mengikat mengenai visi, misi dan program kabinet, di dalam sebuah koalisi harus ada kesepakatan yang mengikat diantara partai-partai yang terlibat. Pada kabinet presidensial, koalisi dapat terbentuk atas kesepakatan antara partai politik dengan presiden, namun belum tentu tercapai kesepakatan diantara partai (Yuda, 2010).

\section{Parliamentary threshold Membatasi Hak Demokrasi}

Demokrasi sejatinya memberi hak yang sama diantara partai politik untuk berkembang dan berkompetisi dalam sebuah pemilihan umum. Setiap partai politik tentunya butuh waktu untuk membesarkan diri dalam setiap pemilihan umum. Electoral Threshold (Syarat partai politik mengikuti pemilu) sangatlah sulit.
Dimana partai politik baru harus mengikuti tahapan-tahapan yang telah di tentukan Kemenhumkam seperti akta notaris, kepengurusan $100 \%$ di tingkat provinsi, $75 \%$ di kabupaten/kota dan 50\% di kecamatan. Tentu semuanya itu harus dilengkapi secara administrasi dan harus di buktikan pula secara faktual.

Kemudian, Sistem Parliamentary threshold akan menimbulkan disproporsional digunakan untuk melihat tingkat keterwakilan pemilih dalam pemilu yang menganut sistem proporsional. Semakin tinggi Indeks disproporsionalitas pada satu pemilu sistem proporsional, maka semakin tidak proporsinallah pemilu itu.

Proporsional itu sendiri dipengaruhi oleh besaran dapil dan juga angka ambang batas parlemen. Karena besaran dapil dan besaran angka ambang batas menyebabkan tingginya suara yang tidak terakomodasi menjadi kursi. Kemudian Parliamentary threshold pasti akan menyebabkan disproporsional antara partai lama dan partai baru. Sebab, dalam hal aktualisasi, kampanye dan penyebaran visi-misi partai sangat terbatas yang biasanya hanya terjadi 2 tahun menjelang pemilu saja. Karena selama ini, partai-partai baru tersebut disibukkan oleh persayaratan administrasi yang memakan energi.

Apabila analisis secara hitoris dan empirik jelas bahwa dalam penentuan angka ambang batas parlemen (Parliamentary threshold) setiap partai politik memiliki kepentingan sendiri dan jauh dari kepentingan masyarakat yang secara khusus memilih mereka. Masingmasing partai politik (fraksi di DPR) hanya mementingkan eksistensinya di 
parlemen dan mempertahankan diparlemen.

Partai-partai kecil dan menengah cenderung mengusulkan angka ambang batas parlemen (parliamentary threshold) sekitar 2,5\%-3,5\%. Hal ini dimaksudkan untuk mempertahakan eksistensi mereka di parlemen. Sementara itu, partai-partai besar cenderung mengusulkan angka ambang batas di atas 4\%-5\%. Hal ini dimaksudkan untuk menghalangi partai-partai kecil yang tidak mendapat dukungan minimal untuk masuk parlemen. kesepakatan mengenai pemberlakuan ambang batas parlemen (parliamentary threshold) menemui jalan buntu karena masing-masing

fraksi mempertahankan kepentingannya sendiri. Kesepakatan mengenai pemberlakuan ambang batas ini akhirnya ditempuh melalui mekanisme voting.

Tarik-menarik kepentingan tersebut kemudian dimenangkan oleh fraksi yang mendukung pemberlakuan ambang batas secara nasional. Fraksi yang mendukung pemberlakuan ambang batas parlemen (parliamentary threshold) secara nasional. Lebih lagi, Mekanisme pengambilan kebijakan soal ambang batas dan metode konversi suara menjadi kursi pun didominasi oleh kepentingan masingmasing partai. Posisi partisipasi masyarakat menjadi tidak berarti, karena kebijakan itu diambil dengan dasar barter politik yang cukup kuat.Produk hukum yang berkarakter reponsif, proses pembuatannya bersifat partisipatif, yakni mengundang sebanyakbanyaknya partisipasi masyarakat melalui kelompok-kelompok sosial dan individu di dalam masyarakat (Wolo, 2015).

Dilihat, secara substansi dan berkarakter penentuan angka ambang batas parlemen (Parliamentary threshold) seharusnya responsif bersifat aspiratif. Artinya memuat materi-materi yang secara umum sesuai dengan aspirasi atau kehendak rakyat yang menjadi fokus tujuan karena merupakan baian yang tidak terpisahkan dari rakyat. Sehingga produk regulasi undang-undang pemilihan umum dapat disimpulkan sebagai sebagai sebua kehendak rakyat. Bukan sebuah hal yang politis.

\section{SIMPULAN}

Pemilihan umum merupakan bagian yang tidak terpisahkan secara prosedural dalam sistem demokrasi di berbagai negara termasuk Indonesia. Sejak pertama kali diselenggarakan, pemilu di Indonesia tahun 1955 hingga pemilu ke-11 pada tahun 2014. Indonesia telah menggunakan sistem proporsional, baik itu dengan mekanisme terbuka ataupun tertutup. Sistem proporsional dapat mengakomodir golongan minoritas dalam parlemen, hal ini sesuai dengan keragaman masyarakat Indonesia dari segi suku, agama, budaya dan sumber daya alam. Indonesia mulai memperkenalkan sistem ambang batas parlemen (Parliamentary Theshold) melalui regulasi undangundang pemilu Nomor 10 Tahun 2008 yang menetapkan ambang batas $2,5 \%$.

Kemudian di Pemilu berikutnya, pemilu 2014 melalui UU Pemilu Nomor 8 Tahun 2012 naik menjadi $3,5 \%$ dengan semangat penyederhanaan jumlah partai di parlemen. Namun, nyatanya hal 
tersebut tidak terjadi. Sebab, jumlah partai politik hasil pemilu 2009 yang merupakan 9 partai justru bertambah menjadi 10 partai di pemilu 2014. Terdapat permasalahan lain dalam sistem pemilu yang menggunakan Parliamentary Theshold.

Pada setiap pemilu tentu, Indonesia telah belajar untuk selalu memperbaiki kualitas pemilunya. Pemilu yang berkeadilan tentunya, tidak membatasi hak politik masyrakat atau partai politik untuk mengikuti pemilihan umum dan berada di parlemen. Berbagai kekurangan dalam sistem Parliamentary Theshold selama ini sedkit banyaknya menghambat proses demokrasi subtansial hanya sebagai sebuah ilusi. Sebab, di pemilu 2009 ada 29 partai politik yang suaranya hilang akibat sistem ini, kemudian di pemilu 2014 ada 2 partai politik yang suara yang juga hilang akibat sistem ambang batas tersebut. Tentu, sebagai sebuah demokrasi rakyat harus tahu kemana suaranya tersebut. Rakyat yang menjadi bagian yang tidak terpisahkan dari pemilu harus dilihatkan aktif dalam proses undangundang pemilihan umum yang tidak kita saksikan saat ini. Lebih lagi, sistem Parliamentary Theshold selama ini telah membuat diproporsional. Artinya secara nyata, peneliti mengusulkan agar angka Parliamentary Theshold di pemilihan umum adalah nol (0) atau tidak adanya Parliamentary Theshold.

\section{DAFTAR PUSTAKA}

Ambardi, K. (2010), Mengungkap Politik Kartel. Jakarta : Kompas Gramedia Jakarta.
Cangara, H. (2009), Komunikasi Politik: Konsep, Teori, dan Strategi. Jakarta: Rajawali Press.

Nadir, A. (2005), Pilkada Lansung dan Masa Depan Demokrasi, Averroes Perss: Malang.

Meyer, T. (2012), Demokrasi Sosial dan Libertarian, Dua Model yang Bersaing dalam Mengisi Kerangka Demokrasi Liberal, Jakarta: Friedrich Ebert Stiftung.

Verney, D.V \& Lijphart, A. (1995) Sistem Pemerintahan Perlementer dan Presidensial. Jakarta: Raja Grafindo Persada.

Yuda, H.A.R. (2010), Presidensialisme Setengah Hati. Jakarta: PT Gramedia Pustaka Utama.

Alkatiri, Z. (2013), The Words Of Magic Used During The Soeharto's Indonesian New

Order Military Regime Era 1980-1997, Depok : Department of History, University of Indonesia, Vol. 2. No. 1. February 2013.

Bao, H.W. (2015), Problematika Penentuan Ambang Batas Parlemen (Parliamentary Threshold) Untuk Pemilihan Umum Dewan Perwakilan Rakyat Republik Indonesia, Yogyakarta : Universitas Atma Jaya;

Dahlan, M. (2015), Reformulasi Parliamentary Threshold Yang Berkeadilan Dalam Pemilu Legislatif Di Indonesia, Malang : Fakultas Hukum Universitas Brawijaya, hal 5-6.

Hary, I.P, (2014), Political Marketing partai Politik Baru Menuju Pemilu 2019, Depok : Universitas Indonesia.

Handani, N.S. (2015), Formula Penyederhanaan Jumlah Partai Politik Di Parlemen Pada Pemilihan 
Umum Indonesia, Semarang : Pamungkas, Y. (2014), Tinjauan Universitas Diponegoro, hal.85- Ambang Batas Perolehan Suara 87.

Higashikata, $\mathrm{T}$ and Kwamura, $\mathrm{K}$. (2015), Voting behavior in Indonesia from 1999 to 2014 Religious Cleavage or Economic Performance ?, Ide Discussion paper, 152, hal.45-64.

Morje, M.H \& Roessler, P.G. (2006), “Liberalizing Electoral Outcomes in Competitive Authoritarian Regime", American Journal of Political Science, Vol. 50, No. 2, April 2006, Pp. 365-381.

Ummul, S.F. Relevansi Parliamentary Threshold terhadap Pelaksanaan Pemilu yang Demokratis, Surakarta : Fakultas Hukum Universitas Sebelas Maret, Jurnal Konstitusi, Volume 8, Nomor 2, April 2010 ISSN 1829-7706, hal.95-112.

Berdasarkan Undang- Undang Nomor 8 Tahun 2012 Tentang Pemilihan Anggota Dewan Perwakilan Rakyat, Dewan Perwakilan Daerah Dan Dewan Perwakilan Rakyat Daerah Terhadap Undang-Undang Dasar 1945" Jurnal Rechtsvinding volume 3 nomor 1, april 2014, hal.33-50.

Toip, H, (2006), Sistem Pemilihan Umum dan Peran Partai Politik Dalam Proses Pelaksanaan Pemilihan Umum Untuk Memilih Anggota Dewan Perwakilan Rakyat Pada Era Reformasi. Jakarta: Program Pasca Sarjana Fakultas Hukum, Universitas Indonesia 